\title{
PENGARUH BUDAYA ORGANISASI DAN KOMITMEN ORGANISASI TERHADAP KINERJA PEGAWAI PADA KANTOR DISTRIK NAVIGASI KELAS II BENOA DI KEC. DENPASAR SELATAN,KOTA DENPASAR
}

\author{
Ni Putu Novi Nurhana Dewi ${ }^{1}$ \\ Ida Ayu Arini ${ }^{2}$ \\ ${ }^{1,2}$ Fakultas Ekonomi Universitas Ngurah Rai, Bali, Indonesia
}

\begin{abstract}
ABSTRAKSI
Tujuan dari penelitian ini adalah Untuk mengetahui pengaruh budaya organisasi dan komitmen organisasi secara parsial dan simultan terhadap kinerja pegawai pada Kantor Distrik Navigasi Kelas II Benoa. Jumlah sampel yang diambil sebanyak 60 orang, dengan metode penentuan sampel dengan menggunakan teknik jenuh/sensus pada petugas Penjaga Menara Suar. Pengumpulan data adalah dengan cara Observasi,Wawancara,Kuesioner dan Studi dokumentasi.Teknik Analisis Data yang digunakan adalah Analisis Kuantitatif, yaitu Analisis regresi linier berganda, Analisis Determinasi, Analisis Statistik Uji t ( ${ }^{t}$ tab) dan Analisis Statistik Uji F ( $\mathrm{F}_{\text {-test }}$ ) dengan menggunakan bantuan komputer program SPSS version 21.0 for windows. Berdasarkan hasil analisis regresi linier berganda diperoleh persamaan regresi linier berganda $Y=a+b_{1} . X_{1}+b_{2} . X_{2}$ atau $Y=2.067+$ 0.720. $X_{1}+$ 0.101. $X_{2}$. Hasil analisis Determinasi menunjukkan bahwa besarnya sumbangan/kontribusi budaya organisasi dan komitmen organisasi terhadap kinerja pegawai adalah sebesar $73,8 \%$ (persen), sedangkan sisanya $26,1 \%$ (persen) dipengaruhi oleh variabel lain yang tidak diteliti. Berdasarkan hasil analisis dan pembahasan, maka dapat disimpulkan bahwa budaya organisasi dan komitmen organisasi secara parsial berpengaruh positif dan signifikan terhadap kinerja pegawai pada Kantor Distrik Navigasi Kelas II Benoa. Demikian juga halnya dengan budaya organisasi dan komitmen organisasi secara simultan berpengaruh positif dan signifikan terhadap kinerja pegawai pada Kantor Distrik Navigasi Kelas II Benoa.

Kata Kunci : Budaya Organisasi, Komitmen Organisasi, Kinerja Pegawai
\end{abstract}

\begin{abstract}
The purpose of this study is to determine the effect of organizational culture and organizational commitment partially and simultaneously to the performance of employees at the Office of Navigation District Class II Benoa. The number of samples taken as many as 60 people, with the method of determining the sample by using saturation technique / census on the officer of Menara Suar Guard. The data were collected by observation, interview, questionnaire and documentation study. Data Analysis Technique used was Quantitative Analysis, ie Multiple Linear Regression Analysis, Determination Analysis, Statistical Analysis of Test $T$ ( ${ }^{t}$ tab) and Statistical Analysis of $F$ Test (F-test) With the help of computer program SPSS version 21.0 for windows. Based on multiple linear regression analysis, multiple linear regression equation $Y=a+b 1$. $X 1+b 2 . X 2$ or $Y=2.067$ $+0.720 . X 1+0.101 . X 2$. The result of Determination analysis shows that the contribution contribution of organizational culture and organizational commitment to employee performance is $73,8 \%$ (percent), while the rest $26,1 \%$ (percent) is influenced by other variable which is not examined. Based on the results of the analysis and discussion, it can be concluded that organizational culture and organizational commitment partially have a positive and significant impact on the performance of employees at the Office of Navigation District Class II Benoa. Similarly, organizational culture and organizational commitment simultaneously have a positive and significant effect on employee performance at the Benoa Second Class Navigation District Office.

Keywords:Organizational Culture, Organizational Commitment, Employee Performance
\end{abstract}




\section{PENDAHULUAN}

Masyarakat Ekonomi Asean (MEA) yang berlaku sejak tahun 2003 menandai telah dimulainya pasar bebas dimana tujuan diberlakukan pasar bebas adalah untuk mengefektifkan dan mengefesiensikan perdagangan internasional. Globalisasi ekonomi dan kedatangan era perubahan dalam menghadapi perdagangan bebas merupakan tantangan serius bagi para pemimpin dalam mengelola organisasi dalam menghadapi perubahan. Perlu kehati-hatian untuk dapat menyesuaikan diri dengan perkembangan sekaligus menjaga kelangsungan organisasi agar tetap dapat bertahan hidup. Dalam konteks mempertahankan dan mengelola organisasi agar mampu bertahan hidup, peran sumber daya manusia (SDM) mempunyai kedudukan yang sentral.

Setiap organisasi untuk dapat tumbuh dan berkembang dengan baik diperlukan usaha untuk menitik beratkan pada SDM (human resources) guna

menjalankan fungsinya dengan optimal, khususnya menghadapi dinamika perubahan lingkungan yang terjadi. Oleh karena itu kemampuan teknis, teoritis, konseptual, moral dari para pelaku organisasi di semua tingkat (level) pekerjaan sangat dibutuhkan sebagai upaya dalam pencapaian kinerja organisasi. Tantangan utama yang sesungguhnya adalah bagaimana dapat menciptakan sumber daya manusia (SDM) yang dapat menghasilkan kinerja optimal untuk mencapai tujuan didalam keselamatan pelayaran.
Kantor Distrik Navigasi Kelas II Benoa merupakan perusahaan milik Pemerintah yang bergerak dibidang pelayaran meliputi segala sesuatu yang berkaitan dengan Sarana Bantu Navigasi Pelayaran, Survey Hidrografi Alur dan Perlintasan kapal yang memiliki pegawai sebanyak 212 orang yang tersebar di berbagai wilayah Bali dan Nusa Tenggara Barat, diantaranya 57 Orang bertugas di kantor, 39 orang bertugas di Kapal Negara, 61 Orang bertugas di bagian Telekomunikasi pelayaran 3 Orang bertugas di Pengamatan Laut dan 60 Orang bertugas di Penjaga Menara Suar. Oleh karena itu maka data-data pegawai tersebut harus terorganisir dengan baik, terutama dalam bidang absensi pegawai yang bertugas sebagai Penjaga Menara Suar. Pegawai Kantor Distrik Navigasi Kelas II Benoa juga berasal dari berbagai daerah di Indonesia, oleh karena itu setiap pegawai juga memiliki latar belakang budaya daerah yang berbeda.

$$
\text { Budaya organisasi dalam }
$$
penelitian ini merupakan sistem penyebaran kepercayaan dan nilainilai yang berkembang dalam suatu organisasi dan mengarahkan perilaku anggota-anggotanya. Budaya organisasi dapat menjadi instrumen keunggulan kompetitif yang utama, yaitu bila budaya organisasi mendukung strategi organisasi, dan bila budaya organisasi dapat menjawab atau mengatasi tantangan lingkungan dengan cepat dan tepat, maka budaya organisasi akan mampu menjadi faktor kunci keberhasilan organisasi, tetapi dapat pula menjadi faktor utama kegagalan organisasi itu sendiri. 
Budaya masyarakat juga merupakan faktor eksternal yang mempengaruhi kinerja pegawai. Seperti masyarakat di Bali yang akan dihadapkan pada dua pilihan yaitu disatu sisi mereka harus mengikuti awig-awig adat yaitu kewajiban untuk ngayah, sedangkan disisi lain mereka harus tetap bekerja untuk menghidupi keluarganya. Memperhatikan hal tersebut, maka diperlukan komuniksi dan koordinasi yang baik antara pegawai dengan Manajemen, sehingga tidak berdampak pada kinerja pegawai.

Komitmen organisasi dalam penelitian ini merupakan Suatu Setiap Pegawai pada kantor Distrik Navigasi Kelas II Benoa harus taat pada peraturan-peraturan yang selama ini diterapkan oleh kantor Distrik Navigasi Kelas II Benoa yang diantaranya adalah kewajiban yang harus meraka taati adalah hari-hari libur Nasional, Ijin dan Cuti Tahunan, dimana pegawai hanya memiliki Ijin dalam setahun hanya empat kali dan maksimal tujuh hari dalam satu tahun. Namun disisi lain karena antara kebiasaan-kebiasaan adat istiadat penduduk lokal yang sering ada upacara dengan keharusan mereka yang harus bekerja dikantor, maka timbullah komplek peran, yaitu disatu sisi mereka harus mengikuti peraturan-peraturan di desanya, dan disisi lain mereka butuh pekerjaan untuk menghidupi keluarganya.

Kinerja dalam penelitian ini merupakan hasil kerja secara kualitas dan kuantitas yang dicapai oleh seorang pegawai dalam melaksanakan fungsinya sesuai dengan tanggung jawab yang diberikan kepadanya. Kinerja seorang pegawai menjadi penting bagi suatu perusahaan, karena kinerja setiap pegawai merupakan sangat kental dengan adat dan budaya, serta upacara keagamaan. Dalam hal ini pegawai yang beragama Hindu keadaan dimana seorang pegawai memihak pada suatu organisasi dan tujuan-tujuannya, serta berniat memelihara keanggotaan dalam organisasi. Komitmen dalam organisasi akan membuat pegawai memberikan yang terbaik kepada organisasi tempat dia bekerja. Sikap ini berkaitan dengan persepsi tujuan organisasi dan keterlibatannya dalam melaksanakan kerja. Setiap pegawai dalam organisasi

sumbangan bagi tercapainya kinerja setiap fungsi perusahaan (bagian produksi, keuangan, pemasaran). Persoalan sekarang apakah kinerja pegawai yang disumbangkan tersebut sudah sesuai dengan standar yang ditetapkan oleh perusahaan. Jadi dalam hal ini budaya organisasi sangat berperan penting terhadap kinerja pegawai pada Kantor Distrik Navigasi Kelas II Benoa. Secara umum kinerja pegawai pada Kantor Distrik Navigasi Kelas II Benoa khususnya yang bertugas sebagai Penjaga Menara Suar sudah baik, hal ini disebabkan karena absensinya memakai fringerprint. Dengan memakai sistem ini tentu saja ada kebaikan dan kelemahannya, Kelebihannya adalah pegwai dapat mensiasati waktu dimana pada pagi hari mereka datang untuk melakukan absen tepat waktu. Sedangkan selanjutnya mereka meninggalkan kantor dan pada saat jam pulang kerja mereka datang lagi hanya untuk mengabsen.

Pokok permasalahan penelitian ini berdasarkan latar belakang masalah yang dijelaskan, adalah: 
1) Bagaimanakah pengaruh budaya organisasi dan komitmen organisasi secara parsial terhadap kinerja pegawai pada Kantor Distrik Navigasi Kelas II Benoa?

2) Bagaimanakah pengaruh budaya organisasi dan komitmen organisasi secara simultan terhadap kinerja pegawai pada Kantor Distrik Navigasi Kelas II Benoa?

\section{METODE PENELITIAN}

Penelitian ini dilakukan pada

Kantor Distrik Navigasi Kelas II Benoa yang terletak di Jalan Pelabuhan Benoa, Di Kec. Denpasar Selatan, Kota Denpasar, Propinsi Bali, 80222 Indonesia, Kantor Distrik Navigasi Kelas II Benoa memiliki semboyan " Kala Jivam Asti”, yang artinya Keselamatan Jiwa dan Harta di Laut. Masyarakat yang tinggal di sekitaran Pelabuhan benoa bekerja sebagai Nelayan dan Produksi Garam. Benoa merupakan salah satu Desa dari 4 Desa yang ada di kecamatan Denpasar Selatan dengan luas wilayah 49,99 $\mathrm{Km}^{2}$ dengan jumlah penduduk 266.420 Jiwa, yang terdiri dari 136.090 jiwa orang laki-laki dan 130.330 jiwa orang perempuan. Denpasar Selatan terdiri dari 6 kelurahan yaitu, Kelurahan Sesetan, Kelurahan Pedungan, Kelurahan Serangan, Kelurahan Panjer, Kelurahan Sanur, dan Kelurahan Renon. Orbitasi (jarak dari pemerintahan) Desa/Kelurahan Denpasar Selatan terletak $10 \mathrm{Km}$ dari pusat pemerintahan Kota Administratif Denpasar. Obyek penelitian dalam hal ini adalah budaya organisasi, komitmen organisasi dan kinerja pegawai.

Penelitian ini menggunakan data primer dan data sekunder.
Penelitian ini menggunakan metode Analisis Regresi Linier Berganda, Menurut (Sugiyono, 2009:277) Analisis Regresi Linier Berganda di gunakan untuk mengetahui pengaruh budaya organisasi dan komitmen organisasi terhadap kinerja pegawai. dan Analisis Determinasi, Menurut Sudjana (2001:246) Analisis Determinasi digunakan untuk mengetahui seberapa besar sumbangan budaya organisasi dan komitmen organisasi terhadap kinerja pegawai

Selanjutnya untuk pengolahan data dengan menggunakan alat bantu komputer dengan program Statistical Package for the Social Sciences (SPSS) Version 21.00 For Windows. Analisis Statistik uji t (t-test), Analisis Statistik uji t (t-test) digunakan untuk menguji signifikansi pengaruh secara parsial antara Budaya Organisasi dan Komitmen Organisasi terhadap Kinerja Pegawai adalah Pengaruh yang positif atau hanya diperoleh secara kebetulan saja. dan Analisis Statistik Uji F (F-test) Analisis uji F (F-test) digunakan untuk menguji signifikansi pengaruh budaya organisasi $\left(\mathrm{X}_{1}\right)$ dan komitmen organisasi $\left(\mathrm{X}_{2}\right)$, secara simultan terhadap kinerja karyawan (Y) adalah pengaruh yag positif dan signifikan atau hanya diperoleh secara kebetulan saja.

\section{HASIL DAN PEMBAHASAN}

Analisis Regresi Linier Berganda ini digunakan untuk mengetahui pengaruh budaya organisasi dan komitmen organisasi terhadap kinerja pegawai. 
Persamaan garis regresi linier berganda dengan formulasi sebagai berikut : $Y=a+b_{1} X_{1}+b_{2} X_{2}$

Berdasarkan hasil Analisis regresi linier berganda dengan menggunakan bantuan komputer program SPSS

(Statistical Product and Service Solution) version 21,0 for windows dapat dilihat pada Tabel 1 berikut ini.

Tabel 1.

Hasil Analisis Regresi Linier Berganda

\begin{tabular}{lccc}
\hline Model & Regresi & t-hitung & Signifikan \\
\hline Constant & 2.067 & 1.017 & 0.110 \\
Budaya Organisasi $\left(\mathrm{X}_{1}\right)$ & 0.720 & 12.465 & 0.000 \\
Komitmen Organisasi $\left(\mathrm{X}_{2}\right)$ & 0.101 & 2.444 & 0.018 \\
\hline $\mathrm{n}=60$ & & & \\
$\mathrm{R}=0,860$ & & \\
$\mathrm{R}^{2}=0,739$ & & \\
$\mathrm{~F}_{\text {-test }}=80.817$ & & 0.000 \\
\hline
\end{tabular}

Berdasarkan hasil analisis SPSS version 21.0 for windows pada tabel 5.11 didapatkan hasil sebagai berikut:

$$
\mathrm{a} \quad=2.067, \mathrm{~b}_{1}=0.720,
$$
$b_{2} \quad=0.101$ sehingga diperoleh persamaan regresi linier berganda adalah :

$$
\begin{aligned}
& \mathrm{Y}=\mathrm{a}+\mathrm{b}_{1} \mathrm{X}_{1}+\mathrm{b}_{2} \mathrm{X}_{2} \\
& \mathrm{Y}=2.067+0.720 \mathrm{X}_{1}+
\end{aligned}
$$

$0.101 \mathrm{X}_{2}$ memberikan informasi sebagai berikut :

1) Nilai $\mathrm{a}=2.067$ artinya apabila tidak ada perhatian terhadap

3) Nilai $b_{2}=0.101$ artinya jika Komitmen Organisasi $\left(\mathrm{X}_{2}\right)$ ditingkatkan satuan-satua, sedangkan Budaya Organisasi

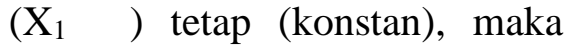

Budaya Organisasi dan Komitmen Organisasi atau nilainya adalah konstan, maka kinerja Pegawai adalah sebesar 2.067.

2) Nilai $b_{1}=0.720$ artinya jika Budaya Organisasi $\left(\mathrm{X}_{1}\right)$ ditingkatkan satusatuan, sedangkan Komitmen Organisasi $\left(\mathrm{X}_{2}\right.$ ) tetap, maka Kinerja Pegawai pada Kantor Distrik Navigasi Kelas II Benoa adalah meningkat sebesar 0.720 satuan.

Kinerja Pegawai pada Kantor Distrik Navigasi Kelas II Benoa adalah meningkat sebesar 0.101 satuan. 


\begin{abstract}
Persamaan regresi ini menunjukkan bahwa ada pengaruh yang positif secara simultan antara Budaya Organisasi dan Komitmen Organisasi terhadap Kinerja Pegawai pada Kantor Distrik Navigasi Kelas II Benoa, koefisien regresi yang bertanda positif berarti ada pengaruh yang secara searah dimana jika secara simultan Budaya Organisasi membaik dan Komitmen Organisasi meningkat, maka akan diikuti oleh meningkatnya kinerja Pegawai pada Kantor Distrik Navigasi Kelas II Benoa.
\end{abstract}

Analisis Determinasi digunakan untuk mengetahui besarnya sumbangan (kontribusi) antara Analisis Uji stasistik (t-tes) digunakan untuk menguji signifikansi pengaruh antara variabel bebas Budaya Organisasi $\left(\mathrm{X}_{1}\right)$ dan Komitmen Organisasi $\left(\mathrm{X}_{2}\right)$ secara parsial terhadap variabel terikat

1) Perumusan Hipotesis

$\mathrm{H}_{0}: \beta_{1}, \beta_{2}=0$, Artinya tidak ada pengaruh yang signifikan antara Budaya Organisasi $\left(\mathrm{X}_{1}\right)$ dan Komitmen Organisasi $\left(\mathrm{X}_{2}\right)$ terhadap Kinerja Pegawai (Y) Pada Kantor Distrik Navigasi Kelas II Benoa, Di Kec. Denpasar Selatan, Kota Denpasar

2) Ketentuan Penyajian

$$
\text { Pada tingkat }
$$
keyakinan $95 \%$ (persen) dan dengan tingkat kesalahan $5 \%$ (persen)

dan df ( degress of fredoom $=$ derajat kebebasan) variabel bebas Budaya Organisasi $\left(\mathrm{X}_{1}\right)$ dan Komitmen Organisasi $\left(\mathrm{X}_{2}\right)$ terhadap variabel terikat Kinerja Pegawai (Y). pada Distrik Navigasi Kelas II Benoa, Di Kec. Denpasar Selatan, Kota Denpasar yang dinyatakan dalam persentase.

Berdasarkan pada tabel. 1 diperoleh nilai koefisien Determinasi sebesar 0,739 artinya Budaya Organisasi dan Komitmen Organisasi memberikan sumbangan/kontribusi terhadap Kinerja Pegawai sebesar $73.9 \%$ (persen), sedangkan sisanya $26.1 \%$ (persen) di sumbangkan oleh faktor-faktor lain yang dalam penelitian ini tidak dibahas.

kinerja Pegawai (Y) adalah pengaruh yang positif dan signifikan atau hanya diperoleh secara kebetulan saja. Langkah-langkah pengujian hipotesis adalah sebagai berikut

Ha : $\beta_{1}, \beta_{2}>0$, Artinya ada pengaruh yang signifikan antara Budaya Organisasi $\left(\mathrm{X}_{1}\right)$ dan Komitmen Organisasi $\left(\mathrm{X}_{2}\right)$ terhadap Kinerja Pegawai (Y) Pada Kantor Distrik Navigasi Kelas II Benoa, Di Kec. Denpasar Selatan, Kota Denpasar .

$=(\mathrm{n}-\mathrm{k}-1)$ test satu sisi pada sisi kanan maka df $=56$, sehingga besarnya $\mathrm{t}$ - table $=$ yang dicari adalah $t(0,05,56)$ adalah sebesar 1.67252 . 
3) Perhitungan thitung

Berdasarkan hasil

analisis dengan

menggunakan

bantuan komputer program

SPSS version 21.0 for windows pada tabel 5.11, maka besarnya t1hitung adalah sebesar t1hitung = 12,465 dan t2hitung $=2,444$

4) Kriteria penerimaan atau penolakan hipotesis

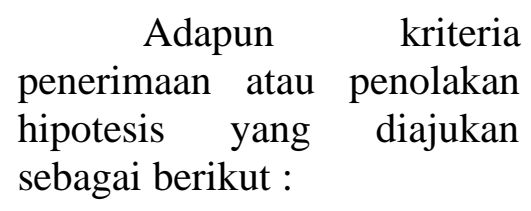

Jika t-hitung $\leq \mathrm{t}-$ table, maka $\mathrm{H} 0$ ditolak Ha diterima

Jika t-hitung $>\mathrm{t}$-table, maka H0 diterima Ha ditolak

5) Kesimpulan

Berdasarkan hasil analisis (t-tes Uji $\beta 1$ ) menunjukkan bahwa nilai (uji $\beta 1)$ diperoleh sebesar 12.465 sedangkan t-tabel sebesar 1.67252. Ternyata nilai t1hitung lebih besar daripada nilai t-tabel atau (uji $\beta 1$ ) $=12.465>$ t-tabel $=1.67252$. Hal ini berarti bahwa Ho ditolak dan $\mathrm{Ha}$ diterima.

1) Perumusan hipotesis

$\mathrm{H} 0: \beta 1, \beta 2=0$, Artinya tidak ada pengaruh antara Budaya Organisasi (X1) dan Komitmen Organisasi (X2) terhadap Kinerja Pegawai (Y) pada Kantor Distrik Navigasi Kelas II Benoa .

Ha $: \beta 1, \beta 2>0$, Artinya ada pengaruh yang positif dan signifikan antara
Artinya bahwa Budaya Organisasi secara parsial mempunyai pengaruh positif dan signifikan terhadap kinerja pegawai.

Berdasarkan hasil analisis (t2test Uji $\beta 2$ ) di atas menunjukkan bahwa nilai t2hitung/uji $\quad \beta 2$ diperoleh sebesar 2.444 sedangkan ttabel sebesar 1.67252 . Ternyata nilai t2hitung lebih besar dari t-tabel atau t2hitung $=2.444>\mathrm{t}$-tabel $=1.67252$. Hal ini berarti bahwa Ho ditolak dan $\mathrm{Ha}$ diterima. Artinya bahwa Komitmen Organisasi secara parsial mempunyai pengaruh positif dan signifikan terhadap kinerja pegawai.

Analisis Uji Statistik F (F-test) ini digunakan untuk menguji signifikansi pengaruh variabel bebas Budaya Organisasi (X1) dan Komitmen Organisasi (X2) secara simultan terhadap variabel terikat kinerja pegawai (Y). Pengujian hipotesis dilakukan dengan menggunakan langkahlangkah pengujian sebagai berikut :
Budaya Organisasi (X1) dan Komitmen Organisasi (X2) terhadap Kinerja Pegawai (Y) pada Kantor Distrik Navigasi Kelas II Benoa

2) Penentuan statistik F-tabel $\propto=0,05$ Pada tingkat keyakinan $95 \%$ (persen) dan dengan tingkat kesalahan 5\% (persen) maka dalam pengujian ini digunakan $\mathrm{F}$-tabel $=\mathrm{F}$ 
(k-1,n-k), untuk $\mathrm{n}=60$ dan $\mathrm{k}=3$ sehingga $\mathrm{df}$ (degress of freedoom)/derajat bebas pembilang adalah $=\mathrm{k}-1=3-1=2$ dan $\mathrm{df}$ (degress of freedoom)/derajat bebas penyebut adalah $=\mathrm{n}-\mathrm{k}=60-3=57$, maka besarnya F-tabel = F $0,05(2,57)=$ 3,16

3) Perhitungan Fhitung

Berdasarkan hasil analisis dengan menggunakan bantuan komputer program SPSS version 21.0 for 5) Menggambarkan daerah penerimaan dan penolakan hipotesis pada derajat bebas pembilang $=2$ dan derajat bebas penyebut $=57$, maka diperoleh besarnya $\mathrm{F}_{\text {-tabel }}=3,16$ dan $\mathrm{F}_{\text {-hitung }}=80,817$.

6) Kesimpulan

Berdasarkan hasil analisis dan gambar di atas menunjukkan bahwa nilai $\mathrm{F}_{\text {-hitung adalah sebesar } 80.817}$ lebih besar dari pada nilai $\mathrm{F}_{\text {-tabel }}=$ 3.16 maka $\mathrm{H}_{0}$ ditolak dan $\mathrm{H}_{\mathrm{a}}$ diterima. Hal ini berarti bahwa antara Budaya Organisasi dan Komitmen Organisasi secara simultan mempunyai pengaruh positif dan signifikan terhadap kinerja pegawai pada Kantor Distrik Navigasi Kelas II Benoa.

Berdasarkan hasil Analisis Regresi Linier Berganda diperoleh $\mathrm{Y}=2.067$ $+0,720\left(\mathrm{X}_{1}\right)+0,101\left(\mathrm{X}_{2}\right)$. Hal ini menunjukkan bahwa meningkatnya Kinerja Pegawai dipengaruhi secara simultan oleh Budaya Organisasi dan Komitmen Organisasi. Dimana pengaruh Budaya Organisasi lebih besar dari pada Komitmen Organisasi.

Berdasarkan hasil analisis menunjukkan bahwa Budaya Organisasi dan Komitmen Organisasi secara simultan mempengaruhi kinerja pegawai, dimana Budaya windows pada tabel 5.11 maka besarnya Fhitung adalah sebesar $=$ 80,817 .

4) Kriteria penerimaan atau penolakan $\mathrm{H} 0$

Adapun kriteria penerimaan atau penolakan hipotesis yang diajukan sebagai berikut :

a) Jika F-hitung < F-tabel, maka H0 diterima dan Ha ditolak

b) Jika F-hitung $\geq$ F-tabel, maka H0 ditolak dan Ha diterima

Berdasarkan hasil analisis di atas, dengan taraf signifikan = Organisasi berpengaruh sebesar 0,720 . Artinya apabila Budaya Organisasi meningkat sebesar satusatuan, maka kinerja pegawai mengalami peningkatan sebesar 0,720 dengan asumsi Komitmen Organisasi konstan. 
Selanjutnya Komitmen Organisasi berpengaruh sebesar 0,101. Artinya apabila Komitmen Organisasi meningkat satu-satuan, maka kinerja pegawai mengalami peningkatan sebesar 0,101 dengan asumsi Budaya Organisasi konstan. Jadi dengan demikian Budaya Organisasi dan Komitmen Organisasi secara simultan/bersama-sama berpengaruh positif dan signifikan terhadap kinerja pegawai pada Kantor Distrik Navigasi Kelas II Benoa.

Berdasarkan hasil analisis uji signifikansi koefisien regresi dengan menggunakan uji statistik $\mathrm{t} \quad\left(\mathrm{t}_{\text {-tes }}\right.$ diperoleh $t_{1 \text { hitung }}$ adalah sebesar 12,465 lebih besar daripada $t_{\text {tabel }}=1,67252$, maka $\mathrm{H}_{0}$ di tolak dan $\mathrm{Ha}$ diterima. Hal ini berarti bahwa Budaya Organisasi mempunyai pengaruh positif dan signifikan terhadap kinerja pegawai. Selanjutnya berdasarkan hasil analisis

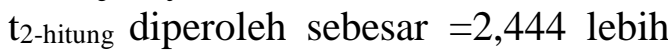
besar dari pada $t_{\text {tabel }}$ sebesar $=1,67252$, maka $\mathrm{H}_{0}$ di tolak dan $\mathrm{Ha}$ diterima. Hal ini berarti bahwa Komitmen Organisasi mempunyai pengaruh positif dan signifikan terhadap kinerja pegawai.

Selanjutnya dari hasil analisis uji signifikansi koefisien regresi dengan menggunakan uji statistik $\mathrm{F}\left(\mathrm{F}_{\text {tes }}\right)$ diperoleh $F_{\text {hitung }}$ sebesar 80,817 lebih besar dari pada $F_{\text {tabel }}$ sebesar 3,16, maka $\mathrm{H}_{0}$ ditolak dan $\mathrm{Ha}$ diterima. Hal ini berarti bahwa antara Budaya Organisasi dan Komitmen Organisasi secara simultan berpengaruh positif dan signifikan terhadap kinerja pegawai. Artinya semakin bagus Budaya Organisasi dan Komitmen Organisasi maka kinerja pegawai akan semakin meningkat. (Hipotesa terbukti).

Jadi Hipotesis yang diajukan yang berbunyi diduga Budaya Organisasi dan Komitmen Organisasi secara parsial berpengaruh positif dan signifikan terhadap kinerja pegawai. Artinya bahwa semakin bagus Budaya
Organisasi dan Komitmen Organisasi secara parsial, maka kinerja pegawai akan semakin meningkat. (Hipotesis terbukti).

\section{SIMPULAN}

Berdasarkan hasil analisis Regresi Linier berganda diperoleh persamaan $\mathrm{Y}=$ 2.067+0,720X $1+0,101 \mathrm{X}_{2}$. Persamaan ini menunjukkan bahwa Budaya Organisasi berpengaruh sebesar 0.720 . Artinya apabila budaya organisasi meningkat sebesar satu-satuan, maka kinerja pegawai mengalami peningkatan sebesar 0.720 dengan asumsi bahwa komitmen organisasi konstan. Selanjutnya komitmen organisasi berpengaruh sebesar 0.101. Artinya apabila komitmen organisasi meningkat sebesar satu-satuan, maka kinerja pegawai mengalami peningkatan sebesar 0.101 dengan asumsi budaya organisasi konstan. Besarnya kontribusi/sumbangan budaya organisasi dan komitmen organisasi terhadap kinerja pegawai adalah sebesar $73,9 \%$ (persen). Sedangkan sisanya sebesar $26,1 \%$ (persen) dipengaruhi oleh faktor lain yang tidak diteliti.

Berdasarkan hasil analisis Statistik Uji t (t-test) menunjukkan bahwa budaya organisasi dan komitmen organisasi secara parsial mempunyai pengaruh positif dan signifikan terhadap kinerja pegawai pada Kantor Distrik Navigas Kelas II Benoa. Selanjutnya hasil analisis Statistik Uji F (F-test) didapat bahwa budaya organisasi dan komitmen organisasi secara simultan berpengaruh positif dan signifikan terhadap kinerja pegawai pada Kantor Distrik Navigasi Kelas II Beno 
SARAN

1. Diharapkan kepada lembaga/perusahaan Kantor Distrik Navigasi kelas II Benoa, hendaknya memasang CCTV di setiap ruangan, sehingga pegawai yang datang tidak tepat waktu atau yang pulang mendahului akan ketahuan.

2. Perusahaan hendaknya memberikan reword/hadiah secara berkala dalam bentuk finansial khususnya kepada pegawai yang loyal terhadap perusahaaan.

3. Kepada pegawai hendaknya saling menghormati privasi maupun Budaya masingmasing, sehingga kedepannya tidak terjadi kesalah pahaman

\section{REFERENSI}

As'ad, Moh. 2000. Psikologi Industri. Yogyakarta: Penerbit Liberty.

Arikunto,Suharsini,2002. Prosedur Penelitian Suatu Pengantar. Jakarta. Arsara.

Dalimunte, Asfar Halim. 2009. Pengaruh Budaya Organisasi Terhadap Kinerja Pegawai Pada Disnas Informasi Komunitas Informasi Komunikasi dan Pengelola Data Elektronik kota Medan.

Darwito. 2008. Analisis Pengaruh Gaya Kepemimpinan Terhadap Kepuasan Kerja Dan Komitmen Organisasi Untuk Meningkatkan Kinerja Karyawan (Studi Pada RSUD Kota Semarang). Tesis. Semarang : Program Studi Magister
Manajemen Pascasarjana Universitas Diponegoro.

Flippo Edwin, B. 2001. Manajemen Produksi. Penerbit BPFE. Yogyakarta.

Gorda, I Gusti Ngurah. 2006. Manajemen Sumber Daya Manusia. Denpasar : Astabrata Bali.

Handoko, T. Hani. 2003. Manajemen. Yogyakarta: Fakultas Ekonomi Universitas Gadjah Mada.

Hasibuan, Malayu SP. 2002. Manajemen Sumber Daya Manusia. Edisi Revisi, Cetakan Kedelapan. Jakarta: PT Bumi Aksara.

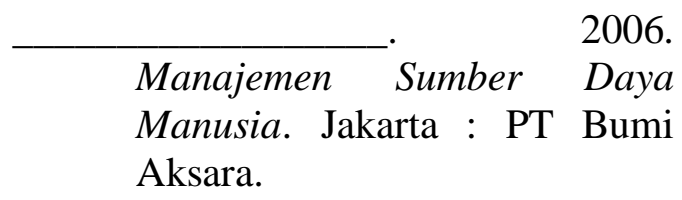

Jaramilloa, F., Prakash, J., \& Marshallc, G. W. 2005. A metaanalysis of the Relationship between Organizational Commitment and Sales- person Job Performance: 25 Years of Research. Journal of Business Research, Vol. 58, 705-714.

Kartiningsih. 2007. Analisis Pengaruh Budaya Organisasi Dan Keterlibatan Kerja Terhadap Komitmen Organisasi Dalam Meningkatkan Kinerja Karyawan (Studi Pada PT. Bank Tabungan Negara (Persero) Cabang Semarang). Tesis. Semarang: Program 
Pasca Sarjana Unversitas Diponegoro.

Kaswan. 2012. Manajemen Sumber Daya Manusia, Untuk Keunggulan Bersaing Organisasi. Yogyakarta: Graha Ilmu.

Kosasih, Niki. 2014. "Analisis Pengaruh Budaya Organisasi Dan Komitmen Keorganisasian Terhadap Kinerja Pegawai (The Analysis Cultural Organizational And Rganizational Effect On Employee Performance)". Jurnal Dinamika Manajemen Vol. 2 No. 3 Juli - September 2014. ISSN: $2338-123 \mathrm{X}$.

Long, M.L. 2000. Consumption Values and Relationship: Sigmenting The Market for Frequensy Programs. Journal of Consumer Marketing, Vol. 17, (3).

Mangkunegara, Anwar Prabu. 2009. Evaluasi Kinerja SDM. Bandung: Penerbit PT. Refika Aditama.

Mangkuprawira, Sjafri. 2011. Manajemen Sumber Daya Manusia Stratejik. Bogor: Penerbit Ghalia Indonesia.

McClelland, D.C. 1987. Human motivation. New York: Press Syndicate of the University of Cambridge.

Moeljono Djokosantoso. 2003. Budaya Korporat dan Keunggulan
Korporasi. Jakarta : Elex Media Komputindo.

Muthuveloo,dkk./et.all. 2005.

Typology of Organisational

Commitment. American Journal of Applied Science. Vol. 2, No. $6: \mathrm{pg}$. 1078-1081, ISSN 1546-9239.

Newstrom, J. W. 2007. Organizational BehaviourHuman Behaviour at work (12th ed). New York: McGraw Hill International Edition.

Nura'eni. 2011. Pengaruh Motivasi, Kompetensi dan Komitmen terhadap Kinerja Dosen Perguruan Swasta di Kopertis Wilayah II Palembang. Palembang. Jurnal Manajemen dan Bisnis Vol. 1 No. 2.

Oei, Istijanto. 2010. Riset Sumber Daya Manusia. Jakarta: Penerbit PT. Gramedia.

Porter, M. E. 1998. On Competition. Boston: Harvard Business School.

Rageb, M. A., El-Salam, E. M. A, Samadicy, A. E, \& Farid, S. 2013. Organizational Commitment, Job Satisfaction and Job Performance as a mediator between Role Stressors and Turnover Intentions A Study from an Egyptian cultural perspective. International Journal of Business and Economic Development, Vol.1 (1), 3454.

Riduwan. 2009. Metode dan Teknik Menyusun Tesis. Bandung: Penerbit Alfabeta. 
Rivai, Veithzal. 2005. Manajemen Sumber Daya Manusia Untuk Perusahaan dari Teori ke Praktik. Jakarta : PT. Raja Grafindo Persada. 2007. Kepemimpinan dan Perilaku Organisasi. Jakarta : PT. Raja Grafindo Persada.

Robbins, Stephen P. 1998. Organizational Behaviour. 1998. New Jersey, New York : Prentice Hall International Inc. 2006. Perilaku

Organisasi Terjemahan. Jakarta : Gramedia.

Robbins, P. Stephen \& Judge, Timothy A. 2008. Perilaku Organisasi. Edisi 12. Jilid 1. Alih Bahasa Diana Angelica dkk. Jakarta: Salemba Empat.

Robbins, Stephen P. 2009. Perilaku Organisasi: Konsep, Kontroversi, Aplikasi, Versi Bahasa Indonesia. Edisi Dua Belas. Jakarta: PT. Prehalindo.

Sagiv, L, \& Schwartz, S. H. 2007. Cultural Values in Organisations: Insights for Europe. European Journal of International Management. http://www.researchgate.net/pro file/Shalom_Schwartz/publicati on/234021865_Cultural_Values _in_Organisations_Insights_for _Europe/links/0c96052bc7de42 cdae000000.pdf. (7 Maret 2012)

Sedarmayanti. 2001. Sumber Daya Manusia Dan Produktivitas
Kerja. Bandung: Penerbit CV. Mandar Maju.

Setiono, Budi. 2000. Jaring Birokrasi, Tinjauan dari aspek Politik dan Administrasi. Jakarta : PT. Gugus Press.

Sinaga,Mangarrisan 2008. Pengaruh Budaya Organisasi dan Reward terhadap Kinerja Karyawan. Medan: PT. Soelong Laoet.

Sinaga, Prima Nugraha S. 2009. Pengaruh Budaya Organisasi Terhadap Kinerja Pegawai Pada Sekretariat Daerah Kabupaten Dairi.

Simamora, H. 1997. Manajemen Sumber Daya Manusia. Yogyakarta: Bagian Penerbitan STIE.

2004. Manajemen Sumber Daya Manusia. Edisi 3. Cetakan 1, Yogyakarta: Penerbit STIE YKPN.

Simanjuntak, Payaman J. 2005. Manajemen dan Evaluasi Kinerja. Jakarta : Lembaga Penerbit Fakultas Ekonomi UI.

Sudjana. 2001. Metode Statistika. Bandung:Tarsito

Sugiyono. 2010. Metode Penelitian Pendidikan Pendekatan Kuantitatif, Kualitatif dan $R \&$ $D$, Bandung : Alfabeta. 
Sugiono,2007. Metode Penelitian Bisnis. Bandung. Penerbit CV. Alfabeta.

Umar, Husein. 2007. Metode Penelitian Untuk Skripsi Dan Tesis Bisnis. Jakarta : PT. Raja Grafindo Persada.

Waridin dan Masrukhin, 2006, "Pengaruh Motivasi Kerja, Kepuasan Kerja, Budaya Organisasi, dan Kepemimpinan Terhadap Kinerja Pegawai", Ekobis, Vol.7, No.2.
Wijaya, Rozy Munarko. 2009. Pengaruh Komitmen Organisasi Dan Penilaian Kinerja Terhadap Kepuasan Kerja Pada Karyawan Bagian Bengkel PT. PAL Di Surabaya. Skripsi. Surabaya: Program Pendidikan Strata Satu Jurusan Manajemen.

Wirawan. 2009. Evaluasi Kinerja Sumber Daya Manusia : Teori Aplikasidan Penelitian. Jakarta : Salemba Empat. 